\title{
Studi Kritik Teori Penciptaan Dalam Kejadian 1:1-2 (Suatu Kajian terhadap Argumentasi Teori Celah)
}

\author{
Djonly Johnson Relly Rosang \\ Sekolah Tinggi Teologi Kalimantan \\ Korespondensi: djonlyjrrosang@sttkalimantan.ac.id
}

\begin{abstract}
Abstrak
Pernyataan Alkitab tentang penciptaan alam semesta sebenarnya sudah tuntas sebagaimana dikemukakan dalam Kejadian 1-2. Namun ada saja orang yang berusaha mencari alasan untuk mempertanyakan proses terjadinya alam semesta ini, sehingga mencoba mencari pertimbangan ilmiah untuk menemukan "pembenaran teoritis" atas kebenaran Alkitab. Tulisan ini bertujuan untuk memberi jawab terhadap teori celah (gap theory) dalam Kejadian 1:1-2, melalui studi biblika penulis mengemukakan argumentasi paham teori celah, dalam kajian metode induktif terhadap studi teks Kejadian 1:1-2. Hasil studi ini disimpulkan bahwa: Pertama, bahwa tidak ada dasar eksegesis yang kuat bagi teori celah untuk memberi ruang bagi asumsi adanya rentang waktu periode atau zaman yang tak terukur dalam proses penciptaan semesta. Kedua, pernyataan Alkitab, "Pada mulanya Allah menciptakan langit dan bumi ... dalam waktu enam hari lamanya” (Kej. 1:1, Kel. 20:11) adalah suatu fakta Alkitab yang tak terbantahkan sebagai tindakan kemahakuasaan dan keagungan Allah menciptakan dunia dari yang tidak ada menjadi ada dengan firman-Nya (creatio ex nihilo). Ketiga, doktrin penciptaan harus menjadi landasan iman Kristen yang diuji dalam otoritas Firman Allah yang berkuasa (2 Tim. 3:16) serta dunia ciptaan Allah dan segala isinya menjadi arena kegiatan ilmiah dalam lintasan sejarah manusia haruslah berdasarkan perspektif Alkitab. Keempat, pernyataan penciptaan Kejadian 1:1 merupakan sanggahan terhadap berbagai teori ilmu pengetahuan dan pandangan filsafat manusia yang bertentangan dengan kebenaran Alkitab (Kej. 1-2, Mzm. 33:4-9).
\end{abstract}

Kata-kata kunci: penciptaan, studi kritik, teori celah

\begin{abstract}
The creation of the universe, according to the Holy Bible has actually done as said in Genesis 1-2. However, there are some people who are still struggling in order to search for the reason to question the process of how is this universe actually began, so that they will look for scientific consideration to find the "theoretical justification" over the biblical truth. This writing aims to give an answer to the gap theory in Genesis 1:1-2. The author, through the study Genesis 1:1-2, the result of this study concluded as follows. First, there is no exegesis background that is strong enough for gap theory to give an assumption that there was an unmeasurably period of time or age in the creation of the universe. Second, a biblical statement, "In the beginning God created the heavens and the earth ... for in six days the LORD made heaven and the earth" (Gen. 1:1; Ex. 20:11) is an ultimate fact of God's power and majesty in creating the earth from nothing to existence with His Word (creatio ex Nihilo). Third, the doctrine of world's creation must be the foundation of faith that is tested in the authority of God's words (2 Thim. 3:16) and the entire creation of God which become the medium of scientifical activity in the history of humanity must be according to the biblical perspective. Fourth, The statement of Genesis 1:1 appears to be refutation toward various scientific theories and human's philosophic perspective that are opposite the biblical truth (Gen. 1-2, Ps. 33:4-9).
\end{abstract}

Keywords: a critical study, creation, gap theory. 


\section{Pendahuluan}

Studi kritik terhadap doktrin penciptaan memang bukanlah merupakan suatu studi yang baru dalam bidang teologi, seiring perkembangan kemajuan pemikiran manusia bagi ilmu pengetahuan dan teknologi yang memunculkan berbagai teori antara iman dan sains sebagai buah kreativitas pemikiran manusia.

Kecenderungan manusia mengakui kemampuan akaliahnya ternyata menggerus keyakinan akan Allah Sang Pencipta, Mahakuasa dan berdaulat atas ciptaan-Nya. Satu di antara banyak teori yang muncul dalam perdebatan mengenai doktrin penciptaan adalah istilah gap theory atau teori celah dalam Kejadian 1:1-2.

\section{Latar Belakang Masalah}

Artikel ini membahas bagian Alkitab yang membicarakan mengenai penciptaan alam semesta yang seharusnya tidak dilihat dari sudut proses terjadinya, tetapi dari perspektif siapa pelaku dan bagaimana peristiwa tersebut dinyatakan (Kej. 1-2, Yoh. 1:1-3). Namun demikian, doktrin penciptaan telah menjadi titik pusat perdebatan antara sains modern dan para teolog, sehingga teologi Alkitab telah diperhadapkan dengan teori-teori yang menolak nilai historis dan ilmiah dari kitab Kejadian. Pada era modern ini justru tekanan pendapat ilmiah telah meningkat, sehingga sebagian sarjana Alkitab telah memberikan kerelaan dan berpengaruh besar dengan meninggalkan tafsiran harafiah naskah Alkitab demi tafsiran yang khayal dan tafsiran yang puitis. ${ }^{1}$ Itulah sebabnya telah terjadi pergeseran nilai akibat pengaruh filsafat dan perkembangan sains dan teknologi. Lebih lanjut W. Stanley Heath dalam Pelurusan Teologi Akhir Zaman menegaskan, "Dari abadabad pertama sampai dengan abad ke-17, kebanyakan teolog berbicara dan menulis berdasarkan Alkitab. Namun karena ada pengaruh dari filsafat sezamannya, tulisan para teolog itu selalu mengandung kekeliruan dan

${ }^{1}$ John J. Davis, Eksposisi Kitab Kejadian, Suatu Telaah (Malang: Gandum Mas, 2001), 35. tidak murni. Dengan kata lain tidak seluruhnya berasal dari Firman Allah. Meskipun demikian, masih banyak teolog yang berusaha menguraikan kebenaran sebaik mungkin. ${ }^{2}$

Jadi pergeseran nilai yang terjadi sejak abad ke-17, sebagai akibat dari ketertarikan akan gagasan hipotesa teori evolusi yang tentunya bertolak belakang dengan kebenaran Firman Allah. Secara tidak sadar mulai terjadi perubahan iman yang meyakini akan Allah adalah Pencipta yang Mahakuasa kepada kebergantungan hasil pemikiran akaliah manusiawi, sehingga berpengaruh juga pada keyakinan terhadap Alkitab yang tanpa salah dan berotoritas dalam hidup manusia (Kej. 1:1; 2 Tim. 3:16). Gleason L. Archer menyatakan, "Kemunculan rasionalisme dan gerakan deisme pada abad kedelapan belas membawa perubahan drastis terhadap status tidak mungkin salah Alkitab ini." ${ }^{3}$ Hal ini telah ditegaskan oleh Arthur Johnston sebagaimana dikutip oleh Chris Marantika dalam buku Kaum Injili Indonesia Masa Kini, yakni, "... mengingatkan bahaya ketergantungan kepada kepandaian manusia dan bukannya pada sumber Allah, yakni pemenuhan diri oleh Roh Kudus." ${ }^{4}$ Salah satu pokok yang paling sering diperdebatkan adalah adanya ketidakcocokan yang antara kisah tentang catatan penciptaan dalam Kejadian 1 dengan bukti yang diduga dari fosil dan mineral yang bisa dibelah menjadi atom dalam lapisan-lapisan geologis yang menunjukkan bahwa umur bumi milyaran tahun. Sedangkan Kitab Kejadian menyatakan bahwa penciptaan terjadi dalam enam hari dimana hari keenam manusia sudah berada di bumi. ${ }^{5}$ Perbedaan antara Kejadian 1 dan data faktual ilmu pengetahuan dalam bidang geologi inilah yang memicu munculnya teori celah dalam Kejadian 1:1-2 dibangun untuk menjembatani rentang waktu abad geologi

${ }^{2}$ W. Stanley Heath, Pelurusan Teologi Akhir Zaman (Bandung: Kalam Hidup 2005), 24.

${ }^{3}$ Gleason L. Archer, Encyclopedia of Bible Difficulties Ucapan-ucapan yang Sulit dalam Alkitab (Malang: Gandum Mas, 2004), 29.

${ }^{4}$ Chris Marantika, Kaum Injili Indonesia Masa Kini (Surabaya: Yakin, t.t.), 10.

${ }^{5}$ Gleason L. Archer, Encyclopedia Bible Difficulties, 94-95. 
tersebut, sehingga Alkitab dapat dicocokkan dengan temuan ilmu pengetahuan yang muncul kemudian.

Pertanyaan pengarah dalam artikel ini adalah: (1). Apakah pernyataan teks Kejadian 1:1-2 mengindikasikan telah pernah ada penciptaan dan terjadi kekacauan, sehingga adanya penciptaan kembali sebagaimana dikemukakan dalam ayat-ayat selanjutnya? (2). Apa sajakah argumentasi yang dibangun paham teori celah untuk menjembatani teori ilmu pengetahuan dengan berita Alkitab? (3). Apakah memang ada dukungan secara gramatika adanya rentang waktu terjadinya penciptaan kembali, sebagaimana dimaksud oleh paham teori celah?

\section{Tesis Statement}

Alkitab adalah Firman Allah tanpa salah dan memiliki otoritas mutlak dalam kehidupan manusia. Oleh karena itu, berita Alkitab mengenai doktrin penciptaan Kejadian 1:1-2 haruslah dipahami dalam otoritas Sang Pelaku sejarah penciptaan dengan karya-Nya yang Agung dan Maha Kuasa. Maka tidaklah bijaksana untuk menyelaraskan pernyataan Alkitab dengan sekadar mencocokkan data ilmu pengetahuan modern melalui gap theory, karena Alkitab haruslah menjadi kajian sumber ilmu pengetahuan dan jawaban satu-satunya bagi pengetahuan asal mula alam semesta yang diciptakan Allah oleh kuasa dan Firman-Nya.

\section{Kajian Historis-Teoritis Kasus Teori Celah}

Teori celah dalam Kejadian 1:1 dan 2, merupakan topik permasalahan yang hangat di kalangan para teolog dan saintis. Teori celah muncul sebagai suatu pembelaan fakta ilmiah terhadap bagian Kitab Suci yang kelihatannya bertentangan dan sulit diterima oleh akal pikiran manusia modern. Kesulitan dalam menafsirkan Kejadian 1:1-2 ini melahirkan teori celah sebagai jawaban atas kisah penciptaan dalam Kejadian 1 terhadap temuan ilmu pengetahuan. Pada hakekat-nya, membela atau mempertahankan bahwa dua ayat pertama dalam Kejadian 1 sebagai suatu tahapan waktu yang panjang berarti meragukan kemahakuasaan dan kedaulatan Allah dalam karya Penciptaan. Kondisi ini pada akhirnya akan melukiskan suatu ketidakpastian tentang waktu enam hari penciptaan dalam Kejadian 1:3-31.

Dari konsep pemikiran di atas, maka dimulailah jejak bagi teori celah. Pandangan ini kemudian diangkat oleh George $\mathrm{H}$. Pember dalam bukunya yang berjudul, Earth's Earliest Ages pada tahun 1876 dan Harry Rimmer dalam bukunya, Modern Science and The Genesis Record tahun $1937^{6}$. Dari uraian di atas terlihat bahwa perkembangan pandangan ini sudah dimulai sejak abad ke-17 oleh Episcopius, melalui pengajaran theologianya di Universitas Leiden Belanda. Juga oleh seorang ahli ilmu pengetahuan yang mendukung pandangan tersebut, yaitu J. G. Rossenmuller tahun 1815 . Pada abad ke-19, gap theory ini terus berkembang ke Inggris melalui beberapa ahli, baik teolog, geolog maupun sejarah gereja. Kemudian diumumkan di Amerika Serikat oleh G.H. Pember dan Harry Rimmer yang akhirnya dimasukkan dalam edisi pertama Scofield Reference Bible. Charles Ryrie menjelaskan landasan berpikir teori celah ialah bahwa, apa yang dinamakan konsep rentangan ini, juga disebut sebagai teori penataan kembali dari kehancuran atau juga teori pemulihan. Ini dibuat untuk menyelaraskan catatan kejadian dengan waktu yang dalam ilmu geologi diperkirakan lama sekali. Prakiraan ini lahir pada saat ilmu pengetahuan mulai maju dan terus berkembang di abad ke-19.?

\section{Kajian Teori Celah dalam Kejadian 1:1 dan 1:2}

Menurut teori ini, antara Kejadian 1:1 dan 1:2 terdapat suatu peredaran waktu yang panjang dan dapat terjadi ribuan tahun bahkan jutaan tahun. Celah inilah yang dimaksud oleh para ilmuwan yang dapat membuktikan keabsahan penemuan geologis masa kini yang telah berjutajuta tahun lamanya. Dari pemahaman terhadap

${ }^{6}$ Merryl F. Unger, Unger's Bibles Handbook (Chicago: Moody Press, 1996), 226.

${ }^{7}$ Unger, Unger's Bibles Handbook, I:246. 
penafsiran Kejadian 1:1 dan 1:2 ini, perlu kajian beberapa istilah penting yang memberikan implikasi lahirnya teori celah ini, kemudian dikorelasikan dengan pernyataan dalam bagian Alkitab lainnya yang adalah merupakan dukungan teori ini.

\section{Titik Awal Penciptaan}

Istilah "pada mulanya" dalam Kejadian 1:1 merupakan suatu kejadian. Rupanya ini menunjuk kepada permulaan penciptaan dunia. Dalam Biblia Hebraica Stuttgartensia

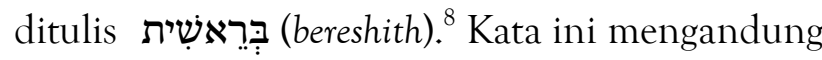
makna yang mengacu kepada judul kitab yaitu Kejadian. Dalam LXX istilah ini disebut Genesis yang artinya "pada mulanya". Archer menjelaskan tentang istilah Genesis sebagai berikut, "The title Genesis (beginning, Greek) was apllied to this book by the Septuagint. The Hebrew title consist of the first word or two in the book, (bereshith) (in the beginning). ${ }^{10}$

"Pada mulanya" menunjuk kepada suatu permulaan waktu, ketika waktu mulai ada. ${ }^{11} \mathrm{~J}$. Verkuyl menegaskan berarti terjadi ketika Allah mulai menciptakan langit dan bumi. Dalam terjemahan Alkitab The Living Bible, Kejadian 1:1 ditulis, "When God began creating the heavens and the earth." Pada catatan kakinya dijelaskan bahwa, "When God began creating or in the beginning." 12 Penekanan permulaan di sini terjadi pada saat Allah menciptakan dan inilah permulaan itu. Selanjutnya, Archer menjelaskan bahwa tema atau subjek pokok istilah bereshith adalah berhubungan dengan asal mula, yaitu, "The origin of the created world, of the human race, of the various nations of the earth, and then particularly

${ }^{8}$ Biblia Hebraica Stuttgartensia_(Stuttgart: Deutsche Bibelgesellschaft, 1967), 1.

${ }^{9}$ Donald Guthrie, Peny. Um, Tafsiran Alkitab Masa Kini 1 Kejadian-Ester (Jakarta: Yayasan Komunikasi Bina Kasih/OMF, 1976), I:76.

${ }^{10}$ Gleason L. Archer, A Survey of Old Testament Introduction (Illinois: Tyndale House Publishers, 1973), 179.

${ }^{11}$ J. Verkuyl, Aku Percaya (Jakarta: BPK Gunung Mulia, 1984), 53.

${ }^{12}$ The Living Bible/ New International Version Parallel Bible (Wheaton: Wheaton House Publishers, 1982), 2. of the covenant family which composses the redeemed people of God." 13

Ibrani 11:3, menyatakan bahwa hanya oleh iman akan dimengerti dengan jelas tentang permulaan alam semesta. Iman berhubungan dengan Pencipta, yaitu Allah sendiri, sebagaimana dinyatakan dalam Kejadian 1:1, "pada mulanya adalah Allah yang menciptakan ..." Allah yang menjadi sumber dari permulaan itu.

Identifikasi Allah sebagai Sang Pencipta dalam Kejadian 1:1, menunjuk kepada istilah umum untuk keAllahan yang merupakan sebutan Allah yang sejati. Kata yang digunakan adalah אֶלה (Elohim). ${ }^{14}$. Istilah ini kemudian mengikuti kata kerja yang menunjuk kepada aktivitas Elohim, yakni: בִּרָּר (Bara'). Istilah Elohim memiliki makna majemuk berhubungan dengan yang Ilahi, yaitu yang kuat, pemimpin yang perkasa, keallahan yang tertinggi. Dalam bentuk jamaknya bermakna kuasa dan keagungan-Nya yang luar biasa. Hal ini sejalan dengan yang dijelaskan oleh H. D. M Spence dan Joseph S. Exell sebagai berikut, "God. Elohim either the highest Being to be feared, from Allah, to fear, ... or, more probably, the strong and mighty One, to be Strong... ${ }^{15}$ Hal itu nyata dari tindakan penciptaan dimana Allah adalah penyebab permulaan segala sesuatu. Dengan demikian, identitas Elohim dalam Kejadian 1:1 merupakan penegasan bahwa Allah adalah pemula. Juga sebelum dunia ada, Allah telah ada, sebab Ia memiliki kekekalan, pembentuk segala sesuatu. Merryl F. Unger menjelaskannya, "God in the first phrase of the existence of God, Whose eternal being is assumed and asserted, and in no sense argued and defined. He is presented here as the infinite First Cause, the Originator and Fashioner of all things." 16 Tentunya pernyataan ini sejalan juga dengan frase pertama dalam Injil Yohanes 1:1, "Pada mulanya adalah Firman..." merupakan kesesejajaran waktu dalam Kejadian 1:1 yang

\footnotetext{
${ }^{13}$ Archer, Survey of Old Testament, 179.

${ }^{14}$ Biblia Hebraica Stuttgartensia, 1.

${ }^{15}$ H. D. M Spence dan Joseph-S. Exell, The Pulpit Comentary vol. 1 Genesis-Exodus (Massachusetts: Hendrickson Publishers, t.t.), 2

${ }^{16}$ Unger, Unger's Bibles Handbook 37.
} 
diimplikasikan sebagai asal mula penciptaan alam semesta ini. ${ }^{17}$ Apa yang merupakan jawaban pada awal sebelum Kejadian. 1:1 adalah Allah. Ini juga dinyatakan oleh Yesus dalam Yohanes 17:24; 17:5, bahwa yang ada sebelum dunia dijadikan adalah Allah. Pernyataan dan pengakuan Kejadian 1:1 merupakan penolakan terhadap segala kepalsuan filsafat manusia, seperti pernyataan Sidlow J. Baxter. ${ }^{18}$ Jadi, hasil dari permulaan ciptaan Allah itu membuktikan bahwa Allah ada dan Dia adalah penyebab segala sesuatu yang ada sejak penciptaan.

Tetapi berbagai pemikiran filsafat manusia tidak akan mengurangi makna penciptaan dalam Kejadian 1. John F. Walvoord meneguhkan pernyataan tentang kehadiran Allah melalui kekekalan-Nya dalam Kristus, sebagai berikut, "Pada mulanya adalah Firman dan Firman itu adalah Allah" (Yoh. 1:1). Perkataan "pada mulanya" (Yunani: en arkhē) menunjuk kepada suatu waktu dalam kekekalan masa yang silam yang mustahil kita datangi. Kata kerja yang dipakai juga dipilih untuk menyatakan kekekalan, karena kata "adalah", Yunani, èn berarti keberadaan yang terus menerus. Marcus Dods menyatakan bahwa, 'Firman itu bukannya mulai ada pada mulanya, melainkan pada titik dimana semua yang lainnya mulai ada, Ia telah ada. ${ }^{19}$ Istilah "pada mulanya" dalam Yohanes 1:1 ini dalam bahasa Yunani menggunakan kata

\footnotetext{
${ }^{17}$ Ibid.

${ }^{18}$ Sidlow J. Baxter, Menggali isi Alkitab - Kejadian Ester. Pen. Sastro Soedirjo (Jakarta: Yayasan Komunikasi Bina Kasih/OMF, 2004), p. 23

Pada mulanya Allah ... sangkalan terhadap itu adalah ateisme yang menyangkal adanya Allah.

Pada mulanya Allah ... sangkalan terhadap politheisme yang percaya kepada ilah yang jamak.

Pada mulanya Allah menciptakan ... sangkalan terhadap fatalisme dengan ajarannya tentang kesemenaan hal-hal. Pada mulanya Allah menciptakan ... sangkalan terhadap evolusi dengan ajarannya tentang penjadian tanpa akhir. Allah menciptakan langit dan bumi- sangkalan terhadap pantheisme yang mengajarkan bahwa Allah dan alam semesta itu adalah sama, identik.

Pada mulanya Allah menciptakan langit dan bumisangkalan terhadap materialisme yang menganut paham tentang keabadian benda

${ }^{19}$ John F. Walvoord, Yesus Kristus Tuhan Kita (Surabaya: Yakin, 1969), 16-7.
}

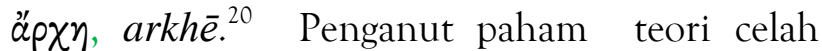
setuju bahwa Allah adalah penyebab pertama atau permulaan dunia ini. Sebagaimana yang dinyatakan dalam Kejadian 1:1.

\section{Penggunaan Istilah בִּרָא Bara'}

Kata yang digunakan dalam bahasa Ibrani untuk istilah "menciptakan" ini adalah bara', adalah kata kerja yang diikuti kata ganti orang sebagai subjek kata kerja, yakni Elohim. Dalam hal ini, Elohim adalah pelaku dari kata bara', sehingga akan memberi arti "membawa suatu pribadi”, memproduksi, meletakkan pada keadaan yang baru dan lebih baik." Pemakaian kata bara' ini hanya dikenakan khusus kepada aktivitas tindakan Allah melalui kuasa-Nya yang tak terbatas. ${ }^{21} \quad$ Kata bara' ini digunakan berkenaan dengan tindakan Allah dalam Kejadian 1:1, 21 dan 27.

R. Haird Larris, Gleason L. Archer dan Bruce K. Waltke memberi pengertian istilah kata bara' adalah, "create, make, Creator (Qal); chose, out down, dispatch (piel); be created, be done (Niphal). ${ }^{22}$ Akar kata bara' sendiri memiliki arti dasar "to create". Ini sinonim dengan yasar, membentuk, dan 'asa, menjadikan. ${ }^{23}$ Dalam pengertian yang khusus tentang Allah, kata bara' adalah tindakan Allah menciptakan dengan tidak menggunakan bahan atau materi yang telah ada. Tetapi suatu tindakan membuat sesuatu yang tidak ada menjadi ada. Sebab sebelum penciptaan tak ada fenomena keberadaan apapun. Creatio ex nihilo adalah suatu konsep untuk memahami kemahakuasaan Allah yang tidak bersifat material. $^{24}$

Teori celah menyatakan bahwa dunia yang pertama telah diciptakan. Namun karena suatu

${ }^{20}$ The Greek New Testament (London: United Bible Society, 1983), 320.

${ }^{21}$ William Wilson, Old Testament Word Studies (Grand Rapids: Kregel Publication, 1978),

101.

${ }^{22} \mathrm{R}$. Laird Harris, Gleason L. Archer, Bruce K. Waltke, Theological Wordbook of the Old Testament Vol. 1 (Chicago: Moody Press, 1981), I:127.

${ }^{23}$ C. Barth, Theologia Perjanjian Lama 1 (Jakarta: BPK Gunung Mulia, 1988), I: 28.

${ }^{24}$ Ryrie, Teologi Dasar, I:245. 
kekacauan atau bencana besar dunia menjadi berantakan. Lalu alam semesta sekarang ini, kemudian diciptakan kembali dari keadaan kacau balau dan kegelapan yang meliputinya (Kej. 1:2). Artinya tinggal semacam renovasi dari suatu kerusakan. Tentu saja ini merupakan pengaruh dari filsafat Yunani Mellisios yang berkata: "Ex nihilo nihil fit, dari ketiadaan tak akan terjadi sesuatupun, penciptaan harus terjadi dari suatu bahan yang sudah ada ... pandangan yang panteistis lazimnya menyatakan bahwa ciptaan itu menjadi bagian dari pencipta." ${ }^{25}$

Teori celah menafsirkan setelah Kejadian 1:1, penciptaan semua, tetapi ayat 2 , terjadi kerusakan, kekosongan sebagai "bumi yang menjadi tanpa bentuk dan kosong”. Jadi ada indikasi bahwa telah terjadi penciptaan sebelumnya yang akhirnya ditimpa oleh suatu bencana yang membawa ketakbentukan atau kehancuran. Karena itu melukiskan suatu kondisi yang jahat akibat kegelapan yang menutupinya, sehingga perlu penataan kembali (Kej. 1:3 dst), sebagai proses penciptaan yang baru seperti yang ada sekarang ini.

\section{Teori Celah dalam Kejadian 1:2}

Menurut teori celah, antara Kejadian 1:1 dan 1:2 terdapat suatu kurun waktu yang panjang dan tak dapat ditentukan. Kejadian 1: 2 dalam King James Version diterjemahkan, "And the earth was without form and void; and darkness was upon the face of the deep..." ${ }^{26}$ Frasa dalam Kejadian 1:2 menurut teori celah dalam penafsirannya, hendaknya diterjemahkan "bumi menjadi tanpa bentuk dan kosong". Hal ini terjadi karena musibah hukuman kepada Iblis. ${ }^{27}$ Dalam Perjanjian Lama Ibrani-Indonesia istilah yang digunakan dalam ayat 2 ini: תהו וָבהו (tohu) wabohu. ${ }^{28}$ Jika tohu wabohu itu terjadi karena

\footnotetext{
${ }^{25}$ Ensiklopedi Indonesia 5 (Jakarta: Ichtiar Baru-Van Hoeve, 1984), V: 2626.

${ }^{26}$ Genesis 1:2 dalam Holy Bible-King James Version (New York: American Bible Society, t.t.), 1.

${ }^{27}$ Ryrie, Teologi Dasar, I:247

${ }^{28}$ Genesis 1:2 dalam Perjanjian Lama Ibrani Indonesia (Jakarta: Lembaga Alkitab Indonesia, 1999, 1.
}

musibah yang ditimpakan sebagai hukuman kepada Iblis, mengapa Allah harus membiarkan kekacauan itu terjadi terhadap ciptaan-Nya? Sebab hasil ciptaan Allah dalam Kejadian 1 selalu disebutnya baik, "maka Allah melihat segala yang dijadikannya itu sungguh amat baik" (Kej. 1:10, 25, 31). Persoalan bagi teori celah adalah menafsirkan kata sambung waw, yang diterjemahkan ke dalam bahasa Inggris was dengan arti "menjadi". Dilihat dari istilah Ibrani, kata sambung "waw" yang dipakai menunjuk kepada proses kelanjutan yang sedang terjadi. Dimana kata ini digunakan berhubungan dengan keadaan dari kata kerja yang mendahuluinya. ${ }^{29} \mathrm{Hal}$ ini dijelaskan lebih lanjut oleh R. Laird Harris yakni, sering digunakan untuk mendahului suatu klausa keadaan dan karena itu diterjemahkan when, since..." ${ }^{30}$

Dalam Alkitab LAI versi terjemahan lama, sebenarnya lebih tepat penerjemahannya, yakni, "pada mulanya Allah menciptakan langit dan bumi. Maka bumi belum berbentuk dan kosong." ${ }^{31}$ Namun demikian, oleh para penganut teori celah kata sambung pemisah waw diterjemahkan "menjadi". Seorang ahli geologi Edwin K. Gedney berkata, "Bahwa penganut teori celah membaca kedua ayat pertama dalam kitab Kejadian sebagai berikut, "pada mulanya Allah menciptakan langit dan bumi. Dan (setelah kurun waktu tak terbatas yang sesuai dengan umur-umur geologis) bumi menjadi tanpa bentuk dan kosong." 32

Penerjemahan dan penafsiran teori celah ini menyatakan bahwa telah ada bumi sebelumnya sejak waktu yang lama, kemudian mengalami suatu bencana dan itulah yang menghancurkan ciptaan semula itu. Di dalam kurun waktu kekosongan itu; yang terdapat dalam Kejadian 1:1, 2 terjadilah kejatuhan malaikat-malaikat. Jadi dalam Kejadian 1:1 dianggap sebagai ciptaan sempurna yang asli, sedangkan ayat 2 mengetengahkan suatu kehancuran akibat

\footnotetext{
${ }^{29}$ Kyle M. Yates, The Essential of Biblical Hebrew (Nashville: Broadman Press, 1938), 64.

${ }^{30}$ R. Laird Harris, dkk., Theological Wordbook, I:229.

${ }^{31}$ Kejadian 1:2 dalam_Alkitab-Terjemahan Lama (Jakarta: Lembaga Alkitab Indonesia, 1970).

${ }^{32}$ Fritz Ridenour, Dapatkah Alkitab Dipercaya? (Jakarta: BPK Gunung Mulia, 1987), 176.
} 
pemberontakan Iblis. Dampak dari penafsiran teori celah ini memengaruhi tafsiran tentang istilah hari penciptaan yang dianggap sebagai kurun waktu yang panjang atau suatu masa panjang sehingga mencakup abad geologi bumi. J. Sidlow Baxter menguraikan pendapat teori celah dengan menyatakan bahwa ayat 2 mengatakan bumi 'kacau dan kosong' memberitakan suatu perubahan besar, sehingga bumi menjadi kosong. Ayat 2 bukan merupakan kelangsungan dari ayat 1; berapa lama selang waktu antara ayat 1 dan 2 tidak diketahui. Dalam ayat 2 seharusnya terdapat perkataan 'menjadi,' sehingga terjemahannya "bumi menjadi kacau dan kosong." Kata Ibrani yang sama dipakai atau terdapat juga dalam Kejadian 2:7, "manusia itu menjadi makhluk yang hidup." 33

Penyelidikan geologi menyatakan bahwa bumi ini telah berjuta-juta abad umurnya, dan dalam hal ini Kejadian tidak bertentangan dengan geologi. Jangka waktu antara ayat 1 dan 2 cukup lama untuk mencakup segala zaman geologis. ${ }^{34}$ Dalam kaitan dengan pernyataan di atas, seakan-akan menyetujui bahwa enam hari dalam penciptaan bukanlah berkenaan dengan penciptaan mula-mula. Kecenderungan uraian di atas adalah ingin mempertemukan fakta ilmiah dengan pernyataan Alkitab, dari pada fakta Alkitab dengan bukti ilmiah. Inilah konsep dasar pemikiran teori celah berkenaan dengan Kejadian 1:1-2. Charles Ryrie menegaskan bahwa, "sesungguhnya pemilihan gramatika dan bentuk terjemahan yang mendukung teori celah adalah lemah dan tidak memiliki dasar eksegesa yang kuat bagi eksegesis nats." 35 Teori celah pada kenyataan memang menjadi populer pada zaman ilmu geologi mulai berkembang. Inilah yang menjadikan orang menerima teori ini karena mudah untuk menampung penemuanpenemuan geologis, sebagai jawab ilmu pengetahuan atas konsep penciptaan berdasarkan kebenaran Alkitab.

\footnotetext{
${ }^{33}$ J. Sidlow Baxter, 24

${ }^{34}$ Ibid.

${ }^{35}$ Ryrie, I:248
}

\section{Argumentasi Paham Teori Celah terhadap Kejadian 1}

Argumentasi Geologis.

Pandangan dunia modern ini, mengatakan bahwa umur bumi berjuta-juta tahun lamanya. Hal ini dihubungkan dengan gap dalam Kejadian 1:1-2. Karena gap theory merupakan rekontruksi dari suatu masa geologis yang panjang, mengakibatkan lahirnya teori-teori lain. Prinsip dogmatis dalam geologi mulai diperkenalkan pada abad ke-18. Geologi historis yang memberikan penekanan kepada proses yang perlahan dan sinambung, memperkenalkan sebuah skala waktu baru yang hampir tidak terbatas untuk evolusi bumi dan masa silam. Ilmu ini tidak mengakui adanya peristiwa sekejap dan bersifat mujizat seperti yang tercantum dalam kisah penciptaan yang ditulis Musa dalam Alktab. Masalah yang menonjol dalam hubungan dengan geologi adalah bahwa dunia menurut geologi evolusioner ilmiah tidak memerlukan campur tangan ilahi. Bahan telah tersedia dan alam semesta serta bumi, dapat berevolusi dengan sendirinya melalui proses waktu yang panjang. Pembuktian-pembuktian ditemukan melalui geologi seperti perkiraan umur bumi yang sudah meliputi jutaan tahun bahkan ratusan juta tahun. Proses lempeng kerak bumi, erosi dan sedimentasi jelas membutuhakan waktu jutaan tahun bagi sejarah bumi.

Pernyataan geologi tersebut di atas tidak akan ditemukan dalam waktu penciptaan enam hari dalam Kejadian pasal 1. Oleh karena itu teori celah membangun argumentasinya pada Kejadian 1:1 dan 2. Skala waktu geologis terdapat antara ayat 1 dan 2, sebagai suatu masa yang tak diketahui. Kurun waktu dalam proses geologis itu adalah seluruh periode dengan segala sesuatu yang terjadi di dalamnya. Karena itu, melalui argumentasi geologis ini teori celah percaya bahwa manusia adalah ciptaan terakhir, sedangkan bumi jauh mendahuluinya. Hal ini diperkirakan 4.500.000.000 S.M., sehingga paham geologis beranggapan bahwa dari dalam penciptaan merupakan suatu bentangan atau tahapan waktu yang panjang. Demikian halnya 
dengan penemuan fosil-fosil yang berusia tua, yang dianggap sebagai suatu kehidupan yang sudah ada sebelum Adam, memberikan bukti bahwa ada suatu waktu yang panjang melalui perubahan geologis. Dari rentangan waktu tersebut maka teori celah membangun konsepnya tentang usia dumia yang telah berjutajuta tahun, sehingga memungkinkan adanya abad geologis.

Argumentasi Istilah "Hari - yom" dalam Kejadian 1

Para penganut teori celah menggali bukti argumentasi melalui istilah "hari" yang digunakan dalam Perjanjian Lama. Teori hari yang merupakan zaman, didasarkan pada pandangan, bahwa kata Ibrani ai (yom) dalam Kejadian 1, yang diterjemahkan "hari" dapat juga berarti "waktu” atau "zaman". Ini merupakan dua paham besar yang saling bertentangan.

Raymond F. Surburg mencatat bahwa kata yom muncul lebih kurang 1480 kali dalam Perjanjian Lama. Ada 50 kali istilah ini diterjemahkan berlainan, seperti "hidup" dan "untuk selamanya", juga selain "hari" dan "waktu". Lebih lanjut Surburg menjelaskan bahwa kata yom dipakai dalam tiga cara pada Kejadian 1:1-2:4, yaitu: dalam Kejadian 1:5, kata "hari" untuk menyatakan bagian yang terang dari hari (sebagai lawan malam), maupun kurun waktu yang tertentu yang disebut sebagai satu hari. Dalam Kejadian 2:3, "hari" jelas dipakai mengacu kepada keenam "hari" yang disebutkan dalam Kejadian 1. Para penganut teori zaman hari menarik kesimpulan bahwa sesungguhnya tidak bisa ditentukan dari konteks Kejadian 1:12:4, berapa lama waktu yang dimaksud oleh kata yom itu. ${ }^{36}$

Sejalan dengan pemikiran di atas, R. A. Jaffray mengomentari istilah "hari" dengan lima cara. Pertama, dalam Kejadian 1:5, istilah siang disebut hari dimana siang itu terdapat terang. Kedua, Kejadian 1:5 selanjutnya ada istilah, "setelah petang dan pagi itulah hari pertama". Pengertian di sini, pagi dan petang yaitu "hari",

\footnotetext{
${ }^{36}$ Ridenour, 82-3.
}

tetapi bukan istilah 24 jam. Ketiga, ayat 14 juga belum menunjuk kepada istilah hari yang 24 jam. Keempat, ayat 16 seperti pernyataan ketiga. Kelima, dalam Kejadian 2:2 juga hari bukan 24 jam. $^{37}$

Penafsiran-penafsiran tentang hari yang bermacam-macam, misalnya suatu tahapan waktu yang panjang, sebagai hari kosmis, sebagai hari Tuhan dan sebagainya, oleh Harun Hadiwijono menyatakan bahwa semuanya itu sukar diterima, sebab tiada landasan sedikitpun dalam Alkitab. ${ }^{38} \quad$ Campbell Morgan setuju dengan istilah "hari" adalah 24 jam sebagai perhitungan hari penciptaan dalam Kejadian 1:3 dan seterusnya. ${ }^{39}$

Charles Ryrie membagi empat pendapat tentang "teori hari" ini dalam empat bahasan. Pertama, hari pada setiap hari penciptaan adalah 24 jam berdasarkan perputaran bumi terhadap matahari. Kedua, hari dipahami sebagai kurun waktu yang panjang atau suatu zaman yang panjang. Pandangan ini memberi peluang kepada penyesuaian masa geologi yang panjang. Ketiga, hari 24 jam dengan rentangan waktu yang panjang di antaranya. Ini menyatakan bahwa hari dalam Kejadian 1 sama dengan matahari, tetapi masing-masing hari tidak segera menyusul hari berikutnya karena terpisah dengan periode yang panjang. Teori hari ini memasukkan teori waktu geologi lapisan tanah. Keempat, teori hari pewahyuan. Pandangan ini menyatakan bahwa hari yang dimaksud tak bersangkut paut dengan pekerjaan Allah dalam penciptaan. Allah hanya menyatakan hal tersebut kepada Musa sebagai ungkapan kejadian dan bukan dalam pelaksanaannya. ${ }^{40}$

Penganut teori celah tentunya mengemukakan bahwa ada dilema, jika hari ditafsirkan sebagai hari 24 jam. Penyebabnya adalah, matahari belum ada walaupun sudah terang. Namun demikian, ilmu pengetahuan

\footnotetext{
${ }^{37}$ R. A. Jaffray, Tafsiran Kitab Kejadian Jilid 1 (Bandung: Kalam Hidup, 1966), 11.

${ }^{38}$ Harun Hadiwijono, Iman Kristen (Jakarta: BPK Gunung Mulia, 1986), 106.

${ }^{39} \mathrm{~J}$. Wesley Brill, Dasar Yang Teguh (Bandung: Kalam Hidup, t.t.), 249

${ }^{40}$ Charles C. Ryrie, Teologi Dasa $r 1$ (Yogyakarta : Yayasan Andi, 1999 ), I:249
} 
terbaru pun menyatakan, bahwa sebelum ada matahari telah terlebih dahulu ada terang yang nampak. Orang percaya meyakini bahwa Allah adalah terang, karena itu terang yang ada berasal dari Allah.

Pendapat lain tentang istilah "hari" dikemukakan oleh J. Sidlow Baxter berhubungan dengan perkataan "kacau dan kosong" dalam Kejadian 1:2. Ini melukiskan keadaan bumi pada mulanya, dengan menyatakan tiga gagasan tentang teori hari ini, sebagai berikut, "Pertama, bahwa hari itu adalah hari yang biasa (24 jam lamanya). Yang mulai segera sesudah bumi dijadikan dalam keadaan kacau dan kosong. Kedua, bahwa enam hari adalah hari yang biasa juga, tetapi tidak segera mulai sesudah bumi dijadikan. Ketiga, bahwa enam hari adalah zaman yang panjang sekali, yang menyusul sesudah bumi dijadikan dalam keadaan yang kacau dan kosong." ${ }^{41}$ Menanggapi tentang teori hari ini, Gleason L. Archer memberi kesimpulan bahwa ada tiga pengertian, yakni , "hari" sebagai hari literal 24 jam; "hari" sebagai yang menunjuk kepada hari penghukuman dan "hari" yang menggambarkan masa geologi atau proses skala waktu yang panjang. ${ }^{42}$ Dari beberapa gagasan tentang hari itu, lebih cenderung kepada penetapan hari yang adalah 24 jam, sebagai hari penciptaan, sekalipun ada berbagai pendapat tentang penafsiran hari. Namun konteks kepenulisan Musa ketika menuliskan Kitab Kejadian tentunya berada pada pengertian hari sebagaimana yang dipahami sekarang ini.

\section{Memahami Makna Teks Kejadian 1:1-2 dari Perspektif Allah dan Karya-Nya}

\section{Allah dan Karya Penciptaan-Nya}

Pernyataan dalam Kejadian 1:1 menyatakan dengan tegas "Pada mulanya Allah menciptakan langit dan bumi." Pernyataan ini menegaskan tentang pribadi Allah dengan sebutan dalam

\footnotetext{
${ }^{41}$ J. Sidlow Baxter, Menggali Isi Alkitab Jil. 1 KejadianEster ( Jakarta: Yayasan Komunikasi Bina Kasih/OMF, 1981), I:34.

${ }^{42}$ Gleason L. Archer, A Survey of Old Testament Introduction (Illinois: Tyndale House Publisher, 1973), 1847.
}

bahasa Ibrani אֶֶה - Elohim sebagai sang Pencipta. Allah itu sudah ada dengan sendirinya, sebab itu Allah tidak memiliki asal mula. Allah ada dalam kekekalan masa lampau dengan kebesaran dan keagungan-Nya. Sebab istilah Elohim menunjuk kepada pribadi Allah yang Maha agung, Maha Kuat, Mata Tinggi dan Dahsyat. Jadi Allahlah yang memulai segala sesuatu dalam totalitas alam semesta ini. Kitab Kejadian merupakan dasar dan titik mula dari pada Firman Allah. Memahami dan mengerti kitab Kejadian berarti akan dapat membangun konsep yang komprehensif dan akurat untuk menerima kebenaran seluruh isi Alkitab.

Penggunaan istilah Allah dalam Kejadian 1:1 bukanlah suatu kebetulan, karena Allah adalah subjek pertama dari kalimat yang pertama dalam Alkitab. Derek Kidner menyatakan sebagai berikut, "It is no accident that God is the subject of the first sentence of the Bible for this word dominates the whole chapter and catches the eye at every point of page: it is used some thirty-five times in as many verse of the story." 43 Dapatlah dikatakan bahwa keseluruhan bagian Alkitab menyatakan tentang Allah dengan segala karya-Nya. Karena itu identifikasi nama Allah dalam Kejadian 1:1 ini merupakan pernyataan supremasi keberadaanNya, seperti dikatakan Jamieson, Fausset dan Brown, "God-the name of Supreme Being, signifying in Hebrew, 'strong', 'Mighty.' It is expressive omnipotent power; and by its use in the plural from, is obscurely taught at the opening of parts of it, that though God is one, these is a plurality of person in the Godhead-Father, Son and Spirit, who were engaged in the creative work (Prov. 8:27; John 1:3, 10; Eph. 3:9; Heb. 1:2; Job. 26:13)." ${ }^{44}$

Jadi makna kata Elohim dalam bentuk jamak terlihat dalam keterlibatan Allah Tritunggal yang kuat, Mahakuasa dalam penciptaan. Kata Elohim banyak digunakan secara umum menunjuk kepada keilahian dalam Firman Allah. Selanjutnya, Elmer L. Towns menjelaskan sebagai berikut, "The Hebrew word of "God" is

${ }^{43}$ Derek Kidner, Genesis (London: Intervaristy Press, 1967), 43.

${ }^{44}$ Robert Jamieson, A. R. Fausset dan David Brown, Commentary Practical and Explanatory On The Whole Bible (Grand Rapids: Zondervan Publishing House, 1978), 17. 
"Elohim" this term comes from two other Hebrew words, El meaning "strong one" and Ohim meaning "to swear or bind with an oath." Therefore, God is the strong one who manifests himself by his word. This name is used over 2.500 times in Old Testament." Elohim adalah nama pertama yang digunakan untuk menyebut Allah dalam Firman-Nya, yakni "Pada mulanya Allah (Elohim) menciptakan langit dan bumi” (Kej. 1:1). Juga dalam Perjanjian Baru kata Allah merupakan referensi terakhir yang digunakan dalam Wahyu 22:19, yang menggunakan istilah Yunani theos. ${ }^{46}$ Jadi Allah sebagai pribadi, sebagai pelaku utama penciptaan dinyatakan dalam Alkitab, bahwa keseluruhan karya dan tindakan-Nya sangat jelas dalam Firman-Nya dari awal sampai akhir. Berarti pengakuan akan Allah (Elohim) yang adalah Pencipta meneguhkan keyakinan untuk memercayai firman Allah sepenuhnya dalam Alkitab, khususnya Kejadian 1. Dimana Allah sendiri telah bertindak dengan keagungan dan kemahakuasaan-Nya menciptakan langit, bumi dan segala isinya sesuai dengan firman-Nya (Mzm. 33:6, 9). Hendrikus Berkhof menegaskan bahwa ada dua statement yang harus selalu dipikirkan orang Kristen ialah, “... pengakuan akan Allah sebagai Pencipta dengan kekuatan ilahi-Nya dan bahwa Allah menciptakan dunia melalui Firman-Nya, dan bahwa Dia menciptakan dari yang tidak ada. ${ }^{\$ 7}$

Bahwa Allah telah menciptakan dengan maksud dan tujuan serta kehendak-Nya, sebagaimana diungkapkan oleh Brill, yakni, "Tuhan Allah, Allah Tritunggal, oleh kehendakNya sendiri, dan untuk kemuliaan-Nya sendiri, telah menciptakan alam semesta, tanpa menggunakan suatu benda, baik yang kelihatan maupun yang tak kelihatan." ${ }^{48}$ Itulah sebabnya, pengungkapan Kejadian 1:1 bahwa "Pada

${ }^{45}$ Elmer L. Towns, What The Faith Is All About (Wheaton, Illinois: Tyndale House Publishers Inc., 1983), 128.

${ }^{46}$ Ibid.

${ }^{47}$ Hendrikus Berkhof, Christan Faith An Introduction To The Study of Faith_(Grand Rapids: Wm. B. Eerdmans Publishing Co., 1979), 135.

${ }^{48} \mathrm{~J}$. Wesley Brill, Dasar yang Teguh_(Bandung: Kalam Hidup, t.t.), 66 mulanya Allah..." merupakan aksioma tertentu pernyataan Alkitab akan penciptaan alam semesta. Allah dalam Kejadian menyatakan diri sebagai Allah Pencipta, sebagai Allah Perjanjian, sebagai Allah Maha Kuasa, sebagai Allah Yang Maha Tinggi, dan Pemilik dari langit dan bumi. $^{49} \quad$ Kemudian dalam tindakan Allah terhadap karya penciptaan ini dinyatakan sebagai asal mula atau asal keseluruhan darimana semuanya telah datang dan ada di semesta jagad raya ini. Dalam Injil Yohanes 1:1 mendukung pernyataan tersebut di atas tentang pengertian "pada mulanya", sebagai awal sejarah tujuh hari itu. Hal ini terkait dengan tindakan ex nihilo yang hasilnya baru sama sekali dan ajaib. Disini bumi dan langit dipandang dalam keadaannya yang terdini dan belum sempurna, namun merupakan suatu totalitas. ${ }^{50}$

Jadi dengan kata lain, Allah dengan kekuatan firman-Nya dan Roh-Nya telah menciptakan dunia, yakni langit dan bumi serta segala isinya. Ini terlihat dalam tahap-tahap penciptaan selanjutnya. Dalam Kejadian 1:2 menyatakan, "Roh Allah melayang-layang..." dan ayat 3, Allah berfirman mengatur dan menciptakan segala sesuatu dalam enam hari. Kemudian Injil Yohanes 1:1-3 menyatakan tentang Allah yang adalah Firman yang menciptakan dan menjadi manusia (Yoh.1:1-3, 14), dan melalui-Nya segala sesuatu telah dijadikan. Paulus menyatakan hal ini juga dalam Kolose 1:16, "Karena di dalam Dialah telah diciptakan segala sesuatu, yang ada di Sorga dan di bumi ... segala sesuatu diciptakan oleh Dia." Joseph Beaumont menyatakan tentang manifestasi dari Allah dan kasih-Nya dalam penciptaan dan tujuan menciptakan yang dikutip oleh Horatius Bonar sebagai berikut, "All things at first was God, who dwelt alone within His boundless self. But bounteous He conceived the form of the creation. That other things by Him might happie be. A way to easy its streams His goodness sought, and at the last into a world burst out."

\footnotetext{
${ }^{49}$ Arthur W. Pink, Glening in Genesis_(Chicago: Moody Press, 1922), p. 10.

${ }^{50}$ Kline, Kejadian dalam TAMK, I:22.

${ }^{51}$ Horatius Bonar, Thoughts On Genesis (Grand Rapids: Kregel Publications, 1979), 2.
} 
Jadi tidak ada keterangan lain tentang segala sesuatu yang ada kecuali Allah sendiri yang menyatakannya. Dia sendiri juga yang telah bertindak mengadakan segala sesuatu. Dia sendiri yang juga telah memulainya dengan menciptakan langit dan bumi. Tak ada pernyataan lain yang dapat membuktikan hal ini selain pernyataan Alkitab dalam Kejadian 1:1. Hal senada dikemukakan oleh Verkuyl, sebagai berikut, "Allah yang kekal Dialah yang menciptakan langit dan bumi. Sebelum itu tidak ada dunia jasmani dan tidak ada dunia rohani. Tidak ada khaos asali. Allah menciptakan dunia tanpa bahan. Hanya dengan FirmanNya dan sabda-Nya. Pada mulanya, yakni ketika pemulaan waktu, ketika waktu mulai ada." ${ }^{52}$

Dengan demikian, tidak ada keraguan bagi orang-orang Kristen untuk meyakini Allah adalah Pribadi yang telah memulai alam semesta ini tanpa memperdebatkannya. Karena itu, penciptaan haruslah merupakan titik tolak dalam melakukan pendekatan pada teologi Alkitab, sebagaimana pengakuan-pengakuan gereja. ${ }^{53}$ Sebab penciptaan merupakan landasan doktrin Kristen bagi doktrin-doktrin selanjutnya, sehingga pengakuan akan karya penciptaan Allah dalam Kejadian 1 sangat penting bagi iman Kristen.

\section{Penggunaan Konjungsi waw ( ! )}

Dalam Kejadian 1:2, kata penting yang patut diperhatikan adalah penggunaan kata sambung atau konjungsi waw. Dalam pengertian bahasa Ibrani, kata sambung pemisah waw ini memiliki beberapa makna. Charles Ryrie menyatakan bahwa, "secara gramatika kata sambung pemisah waw dalam Kejadian 1:2 berarti "adapun" dan bukannya "dan" ${ }^{54}$ Selanjutnya, menurut BrownDriver-Briggs, waw dapat berarti suatu kata sifat demonstrative dan juga konjungsi. Ini dapat diterjemahkan dengan so, then, and. Pengertian

${ }^{52}$ J. Verkuyl, Aku Percaya (Jakarta: BPK Gunung Mulia, 1984), 53.

${ }^{53}$ Donald Guthrie, Teologi Perjanjian Baru (Jakarta: BPK Gunung Mulia, 1991), 47.

${ }^{54}$ Charles C. Ryrie, Theologi Dasar 1(Yogyakarta: Yayasan Andi, 1991), I:249. tersebut menyatakan bahwa, secara umum penggunaan waw lebih menyatakan suatu hubungan. Baik itu menunjukkan hubungan keadaan atau suatu idea atau juga pengantara kepada suatu klausa. Oleh sebab itu dalam menerjemahkan dapat memiliki beberapa arti sesuai dengan konteks kalimat yang dimaksud tersebut.

Penggunaan secara khusus dengan memperhatikan tujuan dan konteks terhadap kata sambung waw dalam Kejadian 1:2 lebih tepat diterjemahkan sebagai waw consecutive. Maksudnya menyatakan bahwa kalimat yang mengikutinya merupakan anak kalimat yang menyatakan keterangan keadaan. Artinya ada kaitan erat dalam melihat konteks Kejadian 1:1 dengan keadaan ayat 2 yang harus dipahami dalam kesatuan gramatika, ketika membaca ataupun melakukan interpretasi terhadap istilahistilah penting untuk mengerti teks yang dimaksud. Hal ini biasanya dipakai dalam bentuk waktu lampau yang sudah dikerjakan. Jadi, Kejadian 1:1 memiliki potensi untuk menjelaskan ini, "Pada mulanya Allah menciptakan langit dan bumi." Ini terjadi pada waktu lampau dan sudah diselesaikan dengan penggunaan istilah bara' sebagai kata kerja dalam bentuk qal, perfect yang berarti sesuatu kegiatan kata kerja telah sempurna dan selesai.

Di dalam penggunaan gramatika perlu dicatat bahwa penggunaannya dibatasi oleh cerita yang dibentuk oleh waw consecutive. Hal ini terlihat jelas dalam Kejadian 1:1 sebagai kalimat dalam bentuk waktu lampau (past tense) dengan kata kerja bara', kemudian diikuti oleh bentuk imperfect dengan didahului oleh prefix waw pada Kejadian 1:2. Komentar Ronald Williams mendukung gagasan di atas, yakni, "With 'consecutive' waw expressing temporal secuence ... or result. 'Consecutive' waw with imperfect originaly the preterite with the early pronounciation of the conjunction archaistically retained as waw,_now equivalent to the perfect aspect in initial position in a clause ..."55 Karena itu secara sederhana, consecutive waw dapat diterjemahkan when

\footnotetext{
${ }^{55}$ Ronald J. Williams, Hebrew Syntax An Outline (London: University of Toronto Press, 1974), 3.3
} 
(bandingkan Kej. 24:19; 7:19; 1 Sam. 15:20). Pendapat ini juga didukung oleh R. Laird Harris, Gleason L. Archer dan Bruce K. Waltke dengan menyatakan bahwa waw dapat berarti: and, so, then, when, now, or, but, that." Namun, jika penggunaannya mendahului suatu klausa keadaan maka selalu diterjemahkan "when, since." Jadi kalimat dalam Kejadian 1:1-2 bukanlah terpisah seperti penafsiran teori celah, dimana kata sambung waw yang diterjemahkan "dan". Maksud pernyataan dalam Kejadian. 1:1-2 yakni, bahwa Allah telah menciptakan langit dan bumi, tetapi masih dalam keadaan kacau dan kosong, tak terbentuk seperti yang digambarkan dalam Kejadian.1:2, kemudian dilanjutkan dengan penataan ciptaan sebagaimana dijelaskan dalam ayat 3 dan seterusnya. Jadi bukanlah dua peristiwa yang terjadi secara terpisah jika ayat 2 dengan kata sambung waw diperlakukan hanya semata-mata sebagai kata penghubung, maka terjemahannya akan lain. Ini akan menjadi berbunyi, "dan bumi menjadi tak terbentuk dan kosong.

Oleh karena itu, jika diamati dalam bentuk gramatika bahasa asli Ibrani, maka tak ada indikasi yang mendukung teori celah. Kidner menyatakan bahwa, "Grammatically, this phrase could be translated as introducing a clause completed in verse 3 after a parenthetical verse 2: 'when God began to create ..." 56 Jika teori celah menyatakan dukungan dalam ayat 2 dengan memilih kata kerja "telah menjadi" maka itu berarti keadaan tersebut terjadi sebelum penciptaan pada ayat 1 . Maka pertanyaannya adalah: Adakah penciptaan lain sebelum ayat 1? Tidak ada satupun indikasi atau keterangan dalam Alkitab yang menyatakan hal itu. Karena itu harus ditolak. Ryrie sekali menegaskan bahwa, sesungguhnya pemilihan gramatika dan bentuk terjemahan ini merupakan dukungan utama bagi teori rentangan, namun karena yang terbaik ini justru lemah, maka disimpulkan bahwa teori tersebut kekurangan dasar yang kuat bagi eksegesis nats. Itulah sebabnya, Kejadian 1:1-2 secara bebas dapat diterjemahkan, "Ketika Allah menciptakan langit dan bumi, (saat itu); adapun bumi belum berbentuk dan kosong; gelap gulita menutupi

\footnotetext{
${ }^{56}$ Derek Kidner, Genesis, 43.
}

samudra raya; dan Roh Allah melayang-layang di atas permukaan air." ${ }^{57}$ Kemudian tahapan selanjutnya dijelaskan dalam ayat 3 dan seterusnya tentang hari-hari penciptaan tersebut. Dengan demikian Kejadian 1:1 merupakan proklamasi awal segala sesuatu ciptaan yang keadaannya seperti dijelaskan ayat 2. Kemudian diatur dan dipersiapkan oleh Allah selama waktu enam hari seperti dijelaskan dalam Kejadian 1:3 dan seterusnya.

Dasar penafsiran ini diletakkan pada istilah tohu wabohu dan tehoom. Menurut Brown-DriverBriggs, istilah תהו (tohu) adalah kata benda yang berarti "formlessness, confusion, unreality, emptiness." K8 Kejadian 1:2 menyatakan bahwa "bumi belum berbentuk dan kosong" (tohu wabohu). Istilah bohu sendiri memiliki pengertian sesuatu yang tak jelas atau kosong. Kata ini digunakan juga ditempat lain dalam Yesaya 34:11 dan Yeremia 4:23 dalam konteks berkaitan dengan tohu. Kedua kata ini memiliki arti yang sama "kosong". Namun Kejadian 1:2, frasa tohu wabohu memiliki variasi pengertian yakni, "a formless waste, absolutely nothing, void and vacancy, without form and void." ${ }^{59}$ Pengertian tersebut seolah memberi ruang yang menggambarkan keadaan alam semesta dalam masa yang dapat mencakup skala waktu bagi teori celah untuk mengakomodasi rekayasa ilmu pengetahuan modern, khususnya dalam temuan ilmu geologi.

Dalam bahasa Yunani, kata tohu wabohu pada Kejadian 1:2 sama dengan kata "outhen" yang artinya "tak ada". Kata ini menerangkan keadaan bumi sebelumnya campur baur, belum berbentuk yang dipakai juga dalam Yeremia 4:23. Namun pengertiannya dinyatakan sebagai suatu keadaan bumi yang tak berbentuk dan kosong diakibatkan karena penghukuman

\footnotetext{
${ }^{57}$ Ryrie, Teologi Dasar, I:248.

${ }^{58}$ Brown, Francis, Charles A. Briggs and S. R.
} Driver, "תהו" dalam The New Brown-Driver-Briggs-Genesius Hebrew and English Lexicon. Massachusetts: Hendricson Publishers, 1979. 1062.

${ }^{59}$ R. Laird Harris, dkk, Theological Wordbook of Old Testament vol.2 (Chicago: Moody Press, 1981), 965. 
Tuhan Allah. ${ }^{60}$ Kemudian, istilah "tohu wabohu" dalam Kejadian 1:2 dijelaskan oleh Harun Hadiwijono yakni, “... menunjuk kepada dunia yang keadaannya belum memungkinkan untuk didiami oleh manusia, karena masih ada bermacam-macam daya yang bekerja, dan yang memungkinkan belum ada makhluk untuk hidup. Bumi sudah ada, sudah berbentuk, hanya belum ada kemungkinan hidup. Kejadian 1:3 dan seterusnya menuju kepada terjadinya dunia yang sekarang teratur ini, yaitu kosmos." ${ }^{61}$ Ketidakmungkinan adanya hidup dalam ayat 2 tersebut dinyatakan dengan istilah תְהוֹ (tehoom), yakni gelap gulita yang menutupi samudra raya. Ini seolah-olah digambarkan sebagai adanya suatu kekuatan lain yang bekerja di dalamnya, jika diaplikasikan dengan penafsiran teori celah berhubungan dengan kegelapan yang masih menutupinya. Di dalam keadaan tak berbentuk dan kacau itulah, maka dimulailah waktu penataan ciptaan selama enam hari dengan kuasa firman Allah. Jadi pernyataan tentang tohu wabohu dalam Kejadian 1:2 bukanlah suatu penghukuman atas setan yang mengakibatkan kehancuran itu terjadi dari hasil penciptaan pertama dalam ayat 1 .

Dari penjelasan di atas dapat disimpulkan bahwa Kejadian 1:2 menunjuk kepada persiapan untuk didiami kemudian, dan bukan sesuatu kekosongan atau kesunyian yang karena pernah didiami lalu karenmerea penghukuman akhirnya menjadi kacau balau dan kosong lagi. Secara sederhana, istilah tohu wabohu yang berarti "campur baur, kosong, tak berbentuk" bukan merupakan suatu keadaan yang pernah terjadi akibat penghukuman atau bencana. Tetapi hal tersebut lebih tepat menyatakan keadaan awal dari proses enam hari penciptaan, dimana bumi itu tidak terdiami, tetapi kemudian didiami setelah enam hari penciptaan itu. Jadi Kejadian 1:2 adalah peristiwa pertama dalam persiapan bagi bumi untuk siap ditempati manusia.

Jadi sangat bertentangan dengan penafsiran teori celah yang menyatakan bahwa Kejadian 1:2 memberitakan keadaan kacau dan kosong yang

${ }^{60}$ Harun Hadiwijono, Iman Kristen (Jakarta: BPK Gunung Mulia, 1986), 163.

${ }^{61}$ Hadiwijono, Iman Kristen, 163 terjadi kemudian setelah penciptaan pertama. Kemudian ayat 3 dianggap sebagai penciptaan kembali untuk tempat bagi manusia yang diciptakan dalam enam hari. Jika demikian halnya, akan muncul pertanyaan. Adakah manusia pra-Adam? Kemana dan dimana manusia pra-Adam itu? Bukankah manusia praAdam juga diciptakan oleh Allah, dan adakah jalan keselamatan bagi mereka? Jelas hal ini tidak disinggung sama sekali dalam Alkitab.

Pada prinsipnya Allah tidak menciptakan bumi supaya kosong, sebab itu bukan tujuan Allah. Tetapi Allah membentuknya dan mengadakan persiapan dalam waktu enam hari untuk layak didiami. Ryrie memberi tanggapan sebagai kesimpulan pengamatan terhadap tohu wabohu sebagai berikut, "Tak terbentuk dan kosong" tak harus menandakan adanya suatu penghukuman dan keadaan jahat. Tohu (tidak berbentuk) muncul di dalam Perjanjian Lama mengacu pada arti ruang (26:7) dan padang belantara (Ul. 32:10) tanpa pengertian adanya suatu kejahatan." ${ }^{\prime 2}$

Karena itu Kejadian 1:2 dalam frasa terakhir merupakan bagian yang patut diperhatikan. Roh Allah melayang-layang di atas permukaan air. Perlu dipahami bahwa susunan kata-kata ini (Kej.1:2) tidak sama dengan Kejadian. 8:1. Kata kerja yang digunakan berbeda. Dalam Kejadian 1:2 digunakan istilah מְרֵֶפת (merahepeth). The Living Bible menerjemahkannya, "... with the Spirit of God brooding over the dark vapors." ${ }^{63}$ Pengertian ini, oleh Stanley M. Norton dijelaskan sebagai berikut, "Kej. 1:2 menyatakan Roh Allah melayang-layang (terus menerus) di atas permukaan air. Kata melayang-layang dalam bentuk yang sama digunakan juga di satu tempat lain lagi (Ul. 32:11). Dalam ayat ini kata tersebut menggambarkan seekor induk burung yang melayang-layang atau giat mengipas-ngipaskan sayapnya di atas anak-anaknya yang hendak melindungi mereka." ${ }^{64}$ Billy Graham mendukung gagasan di atas dengan menyatakan

\footnotetext{
${ }^{62}$ Ryrie, Teologi Dasar, I:248.

${ }^{63}$ The Living Bible-NIV Parallel Bible (Illinois:
} Wheaton House Publishers, Inc., 1982), 1.

${ }^{64}$ Stanley M. Norton, Oknum Roh Kudus (Malang: Gandum Mas, 1976), 17. 
sebagai berikut: "Dalam bahasa Ibrani, kata melayang-layang ini juga berarti mengerami. Sama seperti seekor ayam mengerami telur-telurnya dengan tujuan agar mereka menetas dan membawa kehidupan baru, dengan demikian Roh Kudus mengerami penciptaan asal Allah dengan tujuan untuk mengisi kekosongan dengan hidup dalam berbagai bentuk." ${ }^{65}$

Pengamatan terhadap Kejadian 1;2 dan interpretasi yang Alkitabiah akan dapat memberi jawaban bagi teori celah tanpa harus mencari dukungan bagi permasalahan ini. Merryl F. Unger menyatakan bahwa kedua ayat pertama dalam Kejadian 1 ini merupakan satu kesatuan yang tak terpisahkan, seperti penjelasan berikut ini, "Genesis 1:1 and 1:2 a unit. These two pivotal verse must be separated. They form an introductions to the activity of the seven days (1:3-2:3) because they tell us the condition of the earth when God began to remake or refashion it. It was (not "became") wasteness, emptiness, with darkness upon the survey of the chaotic mass. However, the spirit of God was brooding over the waters..." 66

Dengan perkataan lain, Roh Kudus sebagai satu pribadi Allah Tritunggal dalam penciptaan mengadakan pemeliharaan, menyempurnakan, dan membawa kepada keteraturan. Karena itu tidak ada dasar bagi teori celah manyatakan bahwa ciptaan semula telah ada dan menjadi tak terbentuk akibat suatu bencana. Tak ada indikasi untuk menyatakan itu sekalipun dengan kekacauan dan ketakbentukan. Justru Allah yang telah memulainya dengan meniadakan hal tersebut melalui kuasaNya, sehingga terjadilah alam semesta ini dalam waktu enam hari sesuai dengan kesaksian Firman Tuhan, yakni Alkitab (Kel. 20:11).

\section{Makna Istilah יוֹס (Yom)}

Beberapa pandangan tentang penggunaan pengertian istilah "hari' ini memberi peluang untuk menerima adanya suatu selang waktu yang panjang dalam Kejadian 1:1 dan 1:2. Inilah yang

\footnotetext{
${ }^{65}$ Billy Graham, Roh Kudus (Bandung: Lembaga Literatur Baptis, 1976), 29.

${ }^{66}$ Merryl F. Unger, Unger's Bible Handbook (Chicago: Moody Press, 1966), 38.
}

memungkinkan adanya istilah gap antara ayat 1 dan 2 dalam Kejadian 1. Secara umum kata Ibrani יi dapat berarti suatu periode dari hari yang menyatakan tentang terang dan gelap, atau suatu periode yang panjang dari suatu waktu. ${ }^{67}$ Bagi teori celah, penerimaan terhadap selang waktu yang panjang antara ayat 1 dan 2 dikatakan akan memberi tempat secukupnya kepada zaman geologi tanpa mengurangi nilainilai kebenaran Alkitab. Tapi kenyataannya teori celah mau menempatkan kesejajaran antara teori ilmu pengetahuan dengan Alkitab. Hal ini mengakibatkan enam hari penciptaan bukanlah hari yang biasa. Sidlow Baxter menyatakan yakni, "Bahwa perkataan "hari' dalam Alkitab sering berarti zaman. Jawaban terhadap alasan ini adalah bahwa dimana kata "hari" dipakai dalam arti "zaman", maka ini senantiasa merupakan lambang atau perumpamaan." 68

Pendapat di atas akan memberi peluang kepada penafsiran istilah "hari" yang sebenarnya baru ada setelah matahari diciptakan pada hari keempat. Dengan demikian, maka yang dianggap hari dalam waktu seperti sekarang ini baru terjadi pada hari keempat dan seterusnya. Sedangkan hari-hari penciptaan sebelumnya merupakan revolusi waktu yang cukup panjang. Tetapi ada juga pendapat yang mengatakan bahwa hari yang dimaksud dalam penciptaan adalah hari-hari hidup Musa, yakni 24 jam. Ini sesuai dengan waktu Musa menulis kitab Kejadian. Memang ada banyak argumentasi yang dikemukakan, tetapi jelas bahwa Alkitab sendiri menyatakan, yakni enam hari saja Tuhan Allah menciptakan alam semesta ini (Kej. 1-2, Kel. 20:11). Henry C. Thiessen menyatakannya sebagai berikut, "Several arguments can be advanced: the use of evening and morning, the statement of Exod. 20:11 the appearance of the sun and moon the rule the day and night, the interdependence of the created universe." ${ }^{\text {99 }}$ Disini jelas dinyatakan bahwa hari yang dipakai menyatakan bagian dari terang sebagai lawan

\section{${ }^{67}$ Tenney, The Zondervan Pictorial Bible Dictionary,} 187.

\footnotetext{
${ }^{68}$ J. Sidlow Baxter, Menggali Isi Alkitab, I:38.

${ }^{69}$ Henry C. Thiessen, Lectures in Systematic Theology,
} 101. 
dari gelap yang disebut " satu hari”. Susunan kata-kata dalam Kejadian 1 tampaknya menunjukan suatu waktu yang singkat untuk tindakan-tindakan penciptaan. Tak ada asumsi yang mengisyaratkan suatu masa yang berlangsung lama sekali. Dalam Kejadian 1:3 dan seterusnya, terlihat adanya penekanan pada tindakan seketika Allah dalam menciptakan melalui kuasa Firman-Nya, dengan pernyataan "berfirmanlah Allah: Jadilah ..." Maka segala sesuatu berdasarkan sabda-Nya terjadi seketika sesuai dengan kehendak Allah dalam hari-hari penciptaan.

Dengan demikian bahwa makna penggunaan istilah "hari" yang dimaksud dengan adanya keterangan waktu di setiap hari penciptaan menggunakan "petang dan pagi" secara umum bermakna literal 24 jam dalam konteks hari-hari Musa sebagai penulis kitab Kejadian. Selanjutnya, argumentasi Ryrie terhadap hari ini adalah, "Kata "hari" bila dipakai dengan kata keterangan bilangan yang ada dalam Pentateukh senantiasa menunjuk hari sebagai 24 jam. Lalu mengapa Kejadian 1 harus dikecualikan dari yang lainnya? Pemakaian kata hari dalam pengertian 24 jam di seluruh Perjanjian Lama disertai dengan bilangan atau sebagai kata benda saja. Frasa petang dan pagi dicantumkan di setiap hari penciptaan mendukung arti hari sebagai 24 jam. Keluaran 20:11 dan Keluaran 31:17 menyatakan Allah menciptakan segala sesuatu selama 24 jam Ia beristirahat pada hari ketujuh. Model ini kemudian menjadi siklus mingguan manusia." ${ }^{70}$ Di dalam pekerjaan penciptaan, setiap petang merupakan selesainya pekerjaan yang kemudian diikuti oleh pagi sebagai kegiatan yang baru. Sebab dalam Perjanjian Lama, kata petang dan pagi digunakan kira-kira 100 kali, dan senantiasa dipakai sebagai suatu pengertian yang harafiah sehari 24 jam (Band. Dan. 8:28).

Interpretasi pemakaian "hari" bersama kata bilangan dengan keterangan frasa "petang dan pagi” merupakan juga bukti dalam Kitab Keluaran yang memberi dasar yang kuat bagi penafsiran kata "hari” sebagai waktu 24 jam. Itu

\footnotetext{
${ }^{70}$ Ryrie, Teologi Dasar, I:250.
}

berarti tak ada alasan yang kuat bagi teori celah untuk menafsirkan istilah "hari" sebagai kurun waktu agar dapat mendukung zaman geologis. Allah adalah Pencipta waktu dan Allah tak dapat dibatasi oleh waktu. Allah adalah terang yang merupakan sumber ciptaan itu sendiri sekalipun matahari sebagai penunjuk waktu kini nanti ada pada hari keempat, namun tidak menjadi kendala menyatakan hari penciptaan sebagai waktu yang setiap harinya terdiri dari 24 jam karena berkenaan dengan konteks penulisan kitab Kejajdian oleh Musa sebagai penulisnya yang hidup dalam zaman dengan hari sebagaimana dipahami sekarang ini. Jadi, sangatlah mustahil untuk meragukan akan kemahakuasaan dan kedaulatan Allah dalam melakukan penciptaan dunia ini selama waktu enam hari. Sebab kesaksian Alkitab dalam Kejadian 1 dan bagian-bagian lainnya mendukung hari-hari penciptaan dalam enam hari dan hari ketujuh Allah berhenti dari segala pekerjaan-Nya (Kej. 1-2).

\section{Implikasi Teologis-Aplikatif Konsep Penciptaan}

Doktrin penciptaan merupakan kesimpulan teologi iman Kristen, sebab dari sinilah dimulai segala sesuatu dan merupakan pernyataan pertama dalam Alkitab, "Pada mulanya Allah menciptakan langit dan bumi” (Kej. 1:1). Kalimat ini adalah merupakan pernyataan yang menyangkut keseluruhan doktrin iman Kristen dan totalitas semua ciptaan Allah. Allah menciptakan dunia ini dan isinya dengan tanpa menggunakan sesuatu yang ada sebelumnya. Konsepsi penciptaan dalam Kejadian 1 ini menyatakan bahwa Allah menciptakan dari yang tidak ada menjadi ada (creatio ex nihilo).

Kitab Kejadian yang mengungkap kisah penciptaan ini adalah suatu bagian pernyataan Allah yang menyatakan bahwa dunia dan segala isinya telah diciptakan Allah dalam waktu enam hari. Hal ini dibuktikan dengan dukungan internal Alkitab bagian-bagian lain dalam Alkitab (Kej. 20:11; 31:17; 1 Taw. 1:1; 38:4-7; Mat. 19:4-5; 1 Kor. 11:7-8). Dengan demikian, meragukan kebenaran dalam Kejadian 1:1-2 tentang penciptaan mutlak oleh Allah, serta 
mempersoalkannya dengan menyejajarkan konsep berdasarkan kecocokan data ilmu pengetahuan semata, berarti meragukan seluruh penyataan Allah dalam Firman-Nya. Kesaksian Alkitab sangat jelas dan Alkitab bukan diuji melalui pembuktian ilmiah semata, tetapi justru hasil temuan ilmiah merupakan bukti karya Allah yang harus diuji berdasarkan pernyataan Alkitab, Firman Allah yang berkuasa.

Sebagai orang percaya yang meyakini kebenaran Alkitab adalah Firman Allah, tentu tak perlu takut dan meragukan segala ancaman teori-teori ilmu pengetahuan yang dapat melemahkan iman Kristen. Sebab teori-teori itu adalah hasil rekayasa manusia yang hari ini ada, tetapi kemudian akan berubah. Tetapi Firman Tuhan tak pernah berubah, janji-Nya tak pernah pudar, sekalipun teori-teori ilmu pengetahuan bermunculan. Karena itu pengakuan tentang kebenaran bahwa segala sesuatu mutlak dari Allah dan diciptakan oleh Allah, lebih merupakan soal iman dari pada soal pembuktian ilmiah. Tekananya bahwa alam semesta telah terjadi dan diciptakan Allah dalam enam hari saja (Kej. 1-2, Kel. 20:11).

Keyakinan akan doktrin penciptaan berdasarkan Kejadian 1-2 merupakan landasan keyakinan iman Kristen. Karena itu pengakuan akan keberadaan ciptaan merupakan hasil karya Allah dalam kemahakuasaan-Nya akan memberi kepastian tentang doktrin-doktrin selanjutnya dalam Alkitab. Dengan demikian, orang percaya harus mengakui dan mensyukuri akan keagungan dan kebesaran kuasa Allah dengan takut akan Tuhan sebagai permulaan hikmat dan pengetahuan (Mzm. 111:10; Ams. 1:7). Oleh firman TUHAN langit telah dijadikan, oleh nafas mulut-Nya segala tentaranya. Ia mengumpulkan air laut seperti dalam bendungan, Ia menaruh samudera raya ke dalam wadah. Biarlah segenap bumi takut kepada TUHAN, biarlah semua penduduk dunia gentar terhadap Dia! Sebab Dia berfirman maka semuanya jadi; Dia memberi perintah maka semuanya ada. (Mzm. 33:6-9). "Karena iman kita mengerti, bahwa alam semesta telah dijadikan oleh firman Allah, sehingga apa yang kita lihat telah terjadi dari apa yang tidak dapat kita lihat." (Ibr. 11:3)

\section{Kepustakaan}

Alkitab. Terjemahan Baru. Jakarta: Lembaga Alkitab Indonesia. 1974

Alkitab-Terjemahan Lama. Jakarta: Lembaga Alkitab Indonesia. 1970.

Archer, Gleason L. A Survey of Old Testament Introduction. Illinois: Tyndale House Publishers. 1973.

Archer, Gleason L. Encyclopedia of Bible Difficulties - Ucapan-ucapan yang Sulit dalam Alkitab. Malang: Gandum Mas. 2004.

Barth, C. Theologia Perjanjian Lama 1. Jakarta: BPK Gunung Mulia. 1988.

Baxter, Sidlow J. Menggali isi Alkitab - Kejadian Ester. Pen. Sastro Soedirjo. Jakarta: Yayasan Komunikasi Bina Kasih/OMF. 2004.

Berkhof, Hendrikus. Christan Faith An Introduction To The Study of Faith. Grand Rapids: Wm. B. Eerdmans Publishing Co. 1979.

Biblia Hebraica Stuttgartensia. Stuttgart: Deutsche Bibelgesellschaft. 1967.

Bonar, Horatius. Thoughts On Genesis. Grand Rapids: Kregel Publications Inc. 1979.

Brill, J. Wesley. Dasar yang Teguh. Bandung: Kalam Hidup. t.t.

Brown, Francis, Charles A.Briggs and S. R. Driver, The New Brown-Driver-BriggsGenesius Hebrew and English Lexicon. Massachusetts: Hendricson Publishers, 1979.

Davis, John J. Eksposisi Kitab Kejadian. Suatu Telaah. Malang: Gandum Mas. 2001.

Ensiklopedi Indonesia 5. Jakarta: Ichtiar Baru-Van Hoeve. 1984.

Graham, Billy Roh Kudus. Bandung: Lembaga Literatur Baptis. 1976

Guthrie, Donald. Peny. Um. Tafsiran Alkitab Masa Kini 1 Kejadian-Ester. Jakarta: Yayasan Komunikasi Bina Kasih/OMF. 1976. 
Guthrie, Donald. Teologi Perjanjian Baru. Jakarta: BPK Gunung Mulia. 1991.

Hadiwijono, Harun. Iman Kristen. Jakarta: BPK Gunung Mulia. 1986.

Harris, R. Laird., Gleason L. Archer dan Bruce K. Waltke. Theological Wordbook of Old Testament Vol. 1. Chicago: Moody Press, 1981.

Heath, W. Stanley Pelurusan Teologi Akhir Zaman. Bandung: Kalam Hidup 2005.

Holy Bible-King James Version. New York: American Bible Society. t.t.

Howard, Johathan. Darwin Pencetus Teori Evolusi. Pen. A. Hadyana. Jakarta: Pustaka Utama Graffiti, 1991.

Jaffray, R. A. Tafsiran Kitab Kejadian Jilid 1. Bandung: Kalam Hidup. 1966.

Jamieson Robert., A. R. Fausset dan David Brown. Commentary Practical and Explanatory On The Whole Bible. Grand Rapids: Zondervan Publishing House. 1978.

Kidner, Derek. Genesis. London: Intervaristy Press. 1967.

Kline. Kejadian dalam TAMK. I:22.

Marantika, Chris. Kaum Injili Indonesia Masa Kini. Surabaya: Yakin. t.t.

Norton, Stanley M. Oknum Roh Kudus. Malang: Gandum Mas. 1976.

Pink, Arthur W. Glening in Genesis. Chicago: Moody Press. 1922.

Ridenour, Fritz. Dapatkah Alkitab Dipercaya?. Jakarta: BPK Gunung Mulia. 1987.

Ryrie, Charles C. Theologi Dasar 1. Yogyakarta: Yayasan Andi. 1999

Spence, H. D. M. dan Joseph-S. Exell. The Pulpit Comentary vol. 1 Genesis-Exodus. Massachusetts: Hendrickson Publishers. t.t.

Tenney, Merryl C., Peny. Um. The Zondervan Pictorial Bible Dictionary. Grand Rapids: Zondervan Publishing House, 1992.

The Greek New Testament. London: United Bible Society. 1983.
The Living Bible-New International Version Parallel Bible. Wheaton: Wheaton House Publishers. 1982.

Towns, Elmer L. What The Faith Is All About. Wheaton. Illinois: Tyndale House Publishers Inc. 1983.

Unger, Merryl F. Unger's Bible Handbook. Chicago: Moody Press. 1966.

Verkuyl, J. Aku Percaya. Jakarta: BPK Gunung Mulia. 1984.

Walvoord, John F. Yesus Kristus Tuhan Kita. Surabaya: Yakin. 1969.

Williams, Ronald J. Hebrew Syntax An Outline. London: University of Toronto Press. 1974.

Wilson, William. Old Testament Word Studies. Grand Rapids: Kregel Publication. 1978.

Yates, Kyle M. The Essential of Biblical Hebrew. Nashville: Broadman Press. 1938. 